\title{
Effect of Parenting Style, Academic Environment and Gender on Feeling of Security-Insecurity in Adolescents
}

\author{
Nidhi Malik 1 , Pushpendra Rao upadhyay 2 , Dr. A.C. Vashishtha 3
}

\section{ABSTRACT:}

The present study was designed to explore the role of parenting style, academic environment and gender on feeling of security-insecurity in adolescents. For this purpose a sample of 160 Indian adolescents were selected through quota random sampling. A 2 X2X2 factorial design was used to find out the effect of parenting style, academic environment and gender on feeling of securityinsecurity in adolescents. Obtain raw data were analyzed through Mean, SD and ANOVA. The results indicate that the parenting style, academic environment and gender have significant effect on the feeling of security-insecurity in adolescents.

Keywords: Parenting Styles, Academic Environment, Gender, Feeling of Security-Insecurity,

Adolescents.

\section{INTRODUCTION}

Adolescence is a transitional stage of physical and psychological human development that generally occur during the period from puberty to legal adulthood (Macmillan, 1981; MerriamWebster, 2012; Medline Plus, 2013) and this transitional developments depends on various factors in which parenting style play a key role in development (Baumrind, 1991). Parenting is a complex activity that include many specific behaviors that work individually and together to influence child outcomes Baumrind (1991). Psychologist Diana Baumrind (1971, 1991), Maccoby \& Martin (1983) identified four patterns of parenting styles based upon two aspects of parenting behavior: control and warmth. Authoritative parents are warm but firm. They encourage their adolescent to be independent while maintain limits and control their actions. Authoritative parents engage in discussions and debates with their adolescents. Research makes it clear adolescents of authoritative parents learn how to negotiate and engage in discussion. They understand their opinions are valued. As a result they are more likely to be socially competent, responsible and autonomous.

${ }^{1}$ (Ph.D. Research Scholar) Dept. of Psychology, Meerut College, Meerut.

${ }^{2}$ (Ph.D. Research Scholar) Dept. of Psychology, Meerut College, Meerut.

${ }^{3}$ (Professor) Dept. of Psychology, Meerut College, Meerut.

(C) 2015, N Malik, P Upadhyay, A Vashishtha; licensee IJIP. This is an Open Access Research distributed under the terms of the Creative Commons Attribution License (http://creativecommons.org/licenses/by/2.0), which permits unrestricted use, distribution, and reproduction in any Medium, provided the original work is properly cited. 


\section{Effect of Parenting Style, Academic Environment and Gender on Feeling of Security-Insecurity in Adolescents}

Authoritarian display little warm and highly controlling. They are strict disciplinarians, use restrictive and insist that their adolescent follow parent's directions. Adolescents of authoritarian parents might display aggressive behaviors. Permissive parents are very warm but undemanding. As a result, adolescent may difficulty with self-control and demonstrate egocentric tendencies that can interfere with proper development of peer relations. Uninvolved parents are not warm and not to place any demands on their teen. As a result adolescent generally show impulsive patterns of behavior. These four different type of parenting effect the development of personality. Security-insecurity are two aspects which is highly determine by the personality of adolescent. Security is a state of freedom from any kind of danger to life while insecurity can be defined as emotional instability, feeling of rejection, inferiority anxiety, isolation, jealousy, hostility, irritability in consisting and tendency to accept the worst general permission or unhappy".

\section{METHODOLOGY:}

\section{Objectives:}

1. To study the effect of parenting style on felling of security-insecurity in adolescents.

2. To study the effect of academic environment on felling of security-insecurity in adolescents.

3. To study the effect of gender on feeling of security-insecurity in adolescents.

4. To study the interaction effect between parenting style and academic environment on feeling of security-insecurity in adolescents.

5. To study the interaction effect between parenting style and gender on feeling of securityinsecurity in adolescents.

6. To study the interaction effect between academic environment and gender on feeling of securityinsecurity in adolescents.

7. To study the interaction effect among parenting style, academic environment and gender on the feeling of security-insecurity in adolescents.

\section{HYPOTHESES:}

Following hypotheses were formulated for empirical verification in connection with the fulfillment of the objectives of the present study.

1. Parenting Style (Positive)

2. Academic Environment (CBSE)

3. Gender (Male)

4. Parenting Style

5. Parenting Style

6. Academic Style

7. Parenting Style

$\begin{array}{llll}- & \text { Parenting Style (Negative) } & = & 0 \\ - & \text { Academic Environment (U.P. Board) } & = & 0 \\ - & \text { Gender (Female) } & = & 0 \\ \text { X } & \text { Academic Environment } & = & 0 \\ \text { X } & \text { Gender } & 0 & \\ \text { X } & \text { Gender } & 0 & \\ \text { X } & \text { Academic Environment X Gender } & = & 0\end{array}$




\section{DESIGN OF THE STUDY:}

A 2X2X2 experimental design was employed in the research. The first independent variable of the study was parenting style which was consisted of two groups, i.e. positive parenting style and negative parenting style. The second independent variable of the study was the academic environment that was varied at two levels, i.e. CBSE and U.P. Board. The third independent variable of the study was gender- consisted i.e. male and female. The dependent variable of the study was feeling of security-insecurity in adolescents.

\section{Sample:}

In the present research sample was consisted of 160 male and female adolescent students studied in XI and XII class at various CBSE and U.P. Board Colleges in Delhi NCR region. Subjects with the average age of 21 years were selected through quota-cum random sampling. Out of total subjects $\mathrm{N}=160 ; 80$ subjects were selected who got positive parenting style and rest of 80 subjects got negative parenting style. Total sample of positive and negative parenting style groups was further divided into two sub groups ( $\mathrm{N}=40$ in each group) i.e. CBSE and U.P. Board, further divided in two sub groups $(\mathrm{N}=20)$ male and female.

\section{Tools:}

In this study following tools were used for the measurement of variables under the study

\section{Personal data schedule:}

Personal data sheet was prepared to collect the information about academic environment as positive and negative, class, age, gender, college name, etc.

\section{Parenting style scale:}

Parenting style scale has been used to measure the positive and negative parenting styles of parents of adolescent subjects. This scale was constructed by Dr. C.P. Khokhar (Gurukul kangri University, Haridwar) consisting a total 56 items divided into 7 dimensions (four positive and three negative). The test-retest reliability of the scale for both positive and negative dimensions was respectively 0.58 and 0.87 whereas the split-half reliability of the scale for both positive and negative dimensions was respectively 0.62 and 0.92 . The construct validity of the scale for both positive and negative dimensions was found respectively 0.67 and 0.72 .

\section{The Security-insecurity scale:}

Security-insecurity scale (Hindi version) originally was constructed by Govind Tiwari. This scale consisting a total 70 items including positive and negative. The split-half reliability of the scale was found 0.67 . The test-retest reliability of the scale was found 0.73 . The face validity of the scale was found 0.67 . 


\section{RESULT:}

Findings of the present study were presented in table-1.

Table 1: Summary of ANOVA

\begin{tabular}{|l|l|l|l|l|}
\hline Source of variance & Ss & Df & MS & F \\
\hline A & 46240 & 1 & 46240 & $304.21^{* *}$ \\
\hline B & 13359.02 & 1 & 13359.02 & $410.16^{* *}$ \\
\hline C & 6969.60 & 1 & 6969.6 & $213.98^{* *}$ \\
\hline AB & 4389.03 & 1 & 4389.03 & $134.76^{* *}$ \\
\hline AC & 756.90 & 1 & 756.90 & $23.24^{* *}$ \\
\hline BC & 87.02 & 1 & 87.02 & 2.67 \\
\hline ABC & 403.23 & 1 & 403.23 & $12.38^{* *}$ \\
\hline Error & & 152 & 32.57 & \\
\hline
\end{tabular}

*Significance at .05 level. **Significance at .01 level.

***A group represent parenting style, B group represent academic environment, and C group represent gender of the subject.

Table 2: Mean Scores

(A) Parenting Style:

\begin{tabular}{|l|l|l|}
\hline Dimensions of parenting style & Mean scores & Difference \\
\hline Positive & 157.90 & \multirow{2}{*}{136.00} \\
\hline Negative & 293.90 & \\
\hline
\end{tabular}


(B) Academic Environment:

\begin{tabular}{|l|l|l|}
\hline Dimensions & Mean Scores & Difference \\
\hline C.B.S.E. Board & 189.35 & \multirow{2}{*}{76.10} \\
\hline U.P. Board & 262.45 & \\
\hline
\end{tabular}

(C) Gender:

\begin{tabular}{|l|l|l|}
\hline Type of gender & Mean Score & Difference \\
\hline Male & 199.50 & \multirow{2}{*}{22.50} \\
\cline { 1 - 2 } Female & 252.30 & \\
\hline
\end{tabular}

\section{DISCUSSION:}

A look at the table-1 showing F-ratio of variable ${ }^{(\mathrm{A})}$ parenting style, i.e. positive and negative was found to be $[\mathrm{F}-160(1,152), 304.21, \mathrm{P}<0.01]$ which was found significant at 0.01 level of significance. It means parenting style was an effective variable in influencing feeling of securityinsecurity of adolescents. The mean values for positive and negative parenting styles was respectively 157.90 and 239.90 (difference was 136.00) ; it means who got positive parenting style feel more secure than who got negative parenting style. F-ratio of the variable ${ }^{(\mathrm{B})}$ academic environment, i.e. U.P. board and C.B.S.E. board was found to be [F-160(1,152), 410.16, $\mathrm{P}<0.01]$ which was found to be significant at 0.01 level of significance. It means academic environment was an effective variable in influencing feeling of security-insecurity of adolescent. The mean values for academic environment i.e. U.P. board and C.B.S.E. board was respectively 262.45 and 189.35 (difference was 73.10); it means C.B.S.E. board student feel more secure than the U.P. board students so it can be said that academic environment has positive effect on the feeling of security-insecurity in adolescents. F-ratio of the variable ${ }^{(\mathrm{C})}$ gender i.e. male and female was found to be $[\mathrm{F}-160(1,152), 213.98, \mathrm{p}<0.01]$ which was found to be significant at 0.01 level of the significance. It indicates that the gender was an effective variable for influencing feeling of security-insecurity in adolescent. The mean value for the gender i.e. male and female was respectively 199.50 and 252.30 . This indicated that male adolescents feel more secure than the female adolescents. 
A look at the table-1 showing the interaction effect between the variable ${ }^{(\mathrm{AXB})}$ was found to be [F-160(1,152), 134.76, $\mathrm{p}<.01]$ which indicated that the interaction between parenting style and academic environment (AXB) was found to be effected on feeling of security-insecurity in adolescent at 0.01 level of significance. The interaction effect between the variable ${ }^{(\mathrm{AXC})}$ was found to be $[\mathrm{F}-160(1,152), 23.34, \mathrm{P}<.01]$ which indicated that the interaction between the parenting style and gender (AXC) was found to be effected on feeling of security-insecurity of adolescence at 0.01 level of significance. The interaction effect between the variable ${ }^{(\mathrm{BXC})}$ was found to be $[\mathrm{F}-160(1,152) 2.67, \mathrm{P}>.05]$ which indicated that the interaction between the academic environment and gender was not found to effected on feeling of security-insecurity of adolescent at 0.05 level of significance. The interaction effect among variable ${ }^{(\mathrm{AXBXC})}$ was found to be $[\mathrm{F}-160(1,152) 12.38, \mathrm{P}<.01]$ which indicated that the interaction among all the three variables parenting style, academic environment and gender (AXBXC) was found to be effected on feeling of security-insecurity of adolescents.

\section{REFERENCE:}

1. “Adolescence": Merriam-Webster, Retrieved may 9, 2012.

2. "Puberty and adolescence": Medline plus, Medical Encyclopedia, Retrieved July 22, 2014.

3. Baumrind, D. (1971). Current pattern of parental authority. Developmental Psychology Monograph, 4 (1, pt.2).

4. Baumrind, D. (1991). Effective parenting during the early adolescent transition. In P.A. Cowan \& E.M. Hetherington (Eds.), Advance in family research (Vol. 2). Hillsdale, NJ: Erlbaum

5. Baumrind, Diana. (1991): the journal of early adolescence, Vol. 11 no. 1, page 56-95.

6. Macmillan Dictionary for students Macmillan, Pan Ltd. (1981), page 14,456. Retrieved 2010-7-15.

7. Maccoby, E.E., \& martin, J.A. (1983). Socialization in the context of family: Parent-child interaction. In P.H. Mussen (Ed.) \& E.M. Hetherington (Vol. Ed.), handbook of child psychology: Vol. 4. Socialization, Personality, and Social Development ( ${ }^{\text {th }}$ Ed., pp. 1101). New York: Wiley. 